\title{
Hubungan Pengetahuan Dan Sikap Mahasiswa Program Studi Tata Boga Universitas Negeri Jakarta Dengan Tindakan Penggunaan Plastik Untuk Minuman Panas
}

\author{
Lulu Amalia Octaviany*, Efrina, Alsuhendra
}

Pendidikan Tata Boga, Fakultas Teknik, Universitas Negeri Jakarta

\begin{abstract}
Plastics are organic materials formed into various shapes when exposed to heat and pressure. Plastics have weaknesses and are dangerous for the materials they pack, namely the possibility of migration or transfer of monomer substances from plastic materials into food and beverages. The aims of this research is to analyze the relationship between knowledge and attitudes of student's to measure the use of plastic for hot drinks. This type of this research is survey with cross-sectional approach. The samples in this study are students of the Culinary Education Study Program at the Jakarta State University, with a total sample of 66 respondents using the disproportionate stratified random sampling technique. Data has been analyzed using descriptive analysis and inferential analysis. The results of this research show that the percentage of 66 students who have high knowledge about plastics is $54,5 \%$, $95,5 \%$ of students have high attitudes in using plastic, and $78,8 \%$ of students have high action in using plastic. Meanwhile, the correlation test results showed a positive relationship between student's knowledge and attitudes with the use of plastic ( $r_{-}$count $=0.765>$ r_table $=0.244$ )with a determination coefficient of $58,5 \%$. Based on the research results, it is expected that Culinary Education students will maintain their attitudes and actions in using plastic to avoid the dangers inflicted by plastic.
\end{abstract}

\section{ABSTRAK}

Plastik merupakan bahan organik yang dapat dibentuk ke berbagai bentuk, apabila terpapar panas dan tekanan. Plastik memiliki kelemahan dan berbahaya bagi bahan yang dikemasnya, yaitu adanya kemungkinan terjadinya migrasi atau berpindahnya zat-zat monomer dari bahan plastik ke dalam makanan dan minuman. Penelitian ini bertujuan mengetahui hubungan pengetahuan dan sikap mahasiswa dengan tindakan penggunaan plastik untuk minuman panas. Jenis penelitian ini adalah survei dengan pendekatan cross sectional. Adapun sampel dalam penelitian ini adalah mahasiswa Program Studi Pendidikan Tata Boga Universitas Negeri Jakarta dengan jumlah sampel sebanyak 66 responden yang diambil dengan teknik dispropotionate stratified random sampling. Data dianalisis menggunakan analisis deskriptif dan analisi inferensial. Hasil penelitian menunjukkan bahwa presentase dari 66 orang mahasiswa yang memiliki pengetahuan tinggi tentang plastik sebanyak 54,5\%, sebanyak 95,5\% mahasiswa memiliki sikap tinggi dalam penggunaan plastik, dan sebanyak $78,8 \%$ mahasiswa memiliki tindakan yang tinggi dalam penggunaan plastik. Sedangkan hasil uji korelasi menunjukkan terdapat hubungan yang positif antara pengetahuan dan sikap mahasiswa dengan tindakan penggunaan plastik ( Katursg $=0,765>F_{\text {tabel }}=0,244$ ) dengan koefisien determinasi sebesar 58,5\%.Berdasarkan hasil penelitian diharapkan mahasiswa Pendidikan Tata Boga mempertahankan sikap dan tindakannya dalam penggunaan plastik, sehingga dapat terhindar dari bahaya yang ditimbulkan plastik.
CONTACT

luluocta04@gmail.com

KEYWORDS

Action, Attitude, Knowledge,

Plastic

Received: 28/02/2021

Revised: $25 / 03 / 2021$

Accepted: 30/03/2021

Online: $25 / 04 / 2021$

Published: 30/04/2021

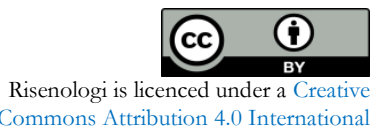

Public Licence (CC-BY 4.0)

\section{INTRODUCTION}

Pangan menjadi kebutuhan dasar manusia yang harus dipenuhi setiap saat.Kelangsungan hidup, pertumbuhan dan perkembangan manusia sangat berkaitan dengan pangan, inilah sebabnya pangan dikatakan sebagai kebutuhan dasar manusia.Produk pangan olahan yang dijual saat ini dikemas dengan berbagai macam bentuk yang menarik.Kemasan memiliki berbagai macam jenis bahan, salah satunya adalah plastik.Menurut Kumar (2011) dalam Surono (2013)plastik adalah salah satu jenis makromolekul yang dibentuk dengan proses polimerisasi. Polimerisasi adalah proses pencampuran beberapa molekul sederhana (monomer) melalui proses kimia menjadi molekul besar (makromolekul atau polimer). Plastik dapat dibentuk ke berbagai bentuk, apabila terpapar panas dan tekanan (Purwaningrum, 2016).

Plastik banyak digunakan berbagai macam produk sebagai kemasan pangan, hal ini dikarenakan keunggulan yang dimiliki oleh plastik.Sifatnya yang fleksibel memudahkan dalam pengemasan mengikuti bentuk pangan, plastik juga sangat ringan sehingga mudah dibawa, tidak mudah pecah, transparan, harganya murah, mudah diberi 
lebel dan dibuat dalam aneka warna, serta dapat di produksi secara massal.Selain memiliki banyak keunggulan, pada jenis tertentu, plastik juga memiliki kelemahan bila digunakan sebagai kemasan pangan, yaitu tidak tahan panas, sehingga plastik dapat dengan mudah meleleh.Plastik juga berpotensi melepaskan migran berbahaya bagi tubuh yang berdampak pada kesehatan bila terus menerus digunakan sebagai kemasan makanan maupun minuman. Perpindahan monomer terjadi karena dipengaruhi oleh suhu makanan atau penyimpanan dan proses pengolahannya. Semakin tinggi suhu tersebut, maka semakin banyak monomer yang dapat berpindah ke dalam makanan. Aditif plastik jenis plasticizer, stabilizer dan antioksidan dapat menjadi sumber pencemaran organoleptik yang membuat makanan berubah rasa serta aroma dan bisa menimbulkan keracunan (Sucipta et al., 2017).

Plastik juga sulit terbiodegradasi, sehingga dapat mencemari lingkungan.Sampah plastik dapat bertahan hingga bertahun-tahun sehingga menyebabkan pencemaran terhadap lingkungan. Sampah plastik tidaklah bijak jika dibakar karena akan menghasilkan gas yang dapat mencemari udara dan membahayakan pernafasan manusia, dan jika sampah plastik ditimbun dalam tanah maka akan mencemari tanah serta air tanah (Karuniastuti, 2013). Tumpukan sampah di Indonesia pada 2016 diketahui mencapai 65,2 juta ton per tahun. Dari jumlah itu, komposisi sampah plastik memiliki andil sebesar 16\%, atau sekitar 10 juta ton ([Kemenkeu RI] Kementrian Keuangan Republik Indonesia, 2019). Sampah plastik dapat mengakibatkan pencemaran terhadap tanah, air tanah, dan makhluk bawah tanah. Bahkan racun dari partikel plastik yang masuk ke dalam tanah akan membunuh hewan pengurai di dalam tanah seperti cacing (Qodriyatun, 2018). Saat ini tercatat 150 juta ton plastik di lautan dunia. Jumlah ini akan meningkat sebesar 250 juta lagi jika tren urbanisasi, produksi, dan konsumsi terus berlanjut (World Bank Group, 2018).Meski terkesan sepele, sampah plastik menimbulkan bahaya yang serius bagi lingkungan dan kesehatan manusia.

Rendahnya kesadaran masyarakat terhadap lingkungan menjadi hal yang sulit untuk diubah. Dalam hal ini, edukasi dan kultur yang ada pada keluarga dan masyarakat turut memiliki andil.Kebiasaan dalam penggunaan plastik baik sebagai kemasan maupun wadah makanan ini juga dapat dilihat di kalangan mahasiswa.Telah dilakukan pengamatan sesaat di Universitas Negeri Jakarta pada bulan Januari 2020, menunjukkan bahwa masih ada mahasiswa yang membeli minuman, khususnya kopi panas di pedagang keliling sekitaran kampus.Selain itu, masih ada mahasiswa yang tidak membawa botol minuman sendiri sehingga membeli botol minum kemasan sekali pakai.Penggunaan kemasan plastik untuk minuman bersuhu panas dan berulang kali menggunakan botol minuman plastik sekali pakai tidaklah dibenarkan.Dalam menggunakan kemasan plastik, perlu memperhatikan simbol/nomor kode daur ulang plastik.Dengan memperhatikan simbol/nomor kode daur ulang plastik, maka tindakan penggunaan plastik yang tidak tepat dapat dihindari.Tujuan penelitian iniadalah mengetahui hubungan antara pengetahuan dan sikap mahasiswa Program Studi Tata Boga Universitas Negeri Jakarta dengan tindakan penggunaan plastik untuk minuman panas.

\section{METHODS}

Tujuan dari penelitian ini adalah untuk mengetahui hubungan pengetahuan dan sikap mahasiswa Pendidikan Tata Boga Universitas Negeri Jakarta dengan tindakan penggunaan plastik untuk minuman panas.Metode yang digunakan adalah metode survei dengan pendekatan cross-sectional.Alat ukur yang digunakan dalam penelitian ini berupa kuesioner atau angket dengan menggunakan data primer.Populasi dalam penelitian ini adalah mahasiswa aktif Program Studi Pendidikan Tata Boga Universitas Negeri Jakarta angkatan tahun 2016 - 2018, yaitu sebanyak 206 orang mahasiswa. Teknik pengambilan sampel pada penelitian ini menggunakan teknik probability sampling dengan dispropotionate stratified random sampling. Besarnya sampel dihitung dengan menggunakan rumus estimasi proporsi, sebagai berikut:

$$
\begin{gathered}
n=\frac{Z^{2} p(1-p) N}{d^{2}(N-1)+Z^{2} p(1-p)} \\
n=\frac{1,96^{2} 0,5(1-0,5) 206}{0,1^{2}(206-1)+1,96^{2} 0,5(1-0,5)} \\
n=\frac{197,84}{2,05+0,96} \\
n=65,72 \sim \text { dibulatkan } 66
\end{gathered}
$$

Keterangan:

$\mathrm{n}$ = Jumlah sampel

$\mathrm{N}=$ Jumlah populasi

$\mathrm{Z}=$ Derajat kepercayaan $(95 \%=1,96)$

$\mathrm{p}=$ Proporsi pada populasi $(0,5)$

$\mathrm{d}=$ Derajat penyimpangan yang diinginkan $(10 \%=0,1)$ 
Besarnya jumlah sampel yang didapatkan dalam penelitian ini adalah 66 responden dengan tingkat kesalahan 10\%.Analisis data dalam penelitian ini menggunakan analisis deskriptif dan analisis inferensial. Dengan menampilkan data berupa distribusi frekuensi, sedangkan analisis inferensial dilakukan menggunakan uji persamaan regresilinier berganda dan koefisien korelasi.

\section{RESULTS AND DISCUSSIONS}

\section{HASIL}

Table 1. Pengetahuan Responden Tentang Plastik

\begin{tabular}{|c|c|c|}
\hline Kategori & $\begin{array}{l}\text { Jumlah } \\
\text { (Orang) }\end{array}$ & Presentase $(\%)$ \\
\hline Tinggi & 36 & 54,5 \\
\hline Sedang & 27 & 40,9 \\
\hline Rendah & 3 & 4,5 \\
\hline TOTAL & 66 & 100 \\
\hline
\end{tabular}

Pada Tabel 1 menunjukkan kategori pengetahuan responden tentang plastik berada pada kategori tinggi sebanyak 36 orang dengan presentase 54,5\%. Berdasarkan hasil skoring dari jawaban responden, maka pengetahuan responden dikatagorikan ke dalam katagori tinggi, sedang atau rendah.

Table 2 Sikap Responden dalam Penggunaan Plastik

\begin{tabular}{|c|c|c|}
\hline Kategori & $\begin{array}{l}\text { Jumlah } \\
\text { (Orang) }\end{array}$ & Presentase $(\%)$ \\
\hline Tinggi & 63 & 95,5 \\
\hline Sedang & 3 & 4,5 \\
\hline Rendah & 0 & 0,0 \\
\hline TOTAL & 66 & 100 \\
\hline
\end{tabular}

PadaTabel 2dapat diketahui kategori sikap responden dengan tindakan penggunaan plastik berada pada kategori tinggi sebanyak 63 orang dengan presentase 95,5\%. Hasil penelitian sikap diukur melalui sikap responden dalam penggunaan plastik, aturan penggunaan plastik, bahaya penggunaan plastik, dan lain-lain.

Table 3. Tindakan Responden dalam Penggunaan Plastik

\begin{tabular}{lccc}
\hline & Kategori & $\begin{array}{c}\text { Jumlah } \\
\text { (Orang) }\end{array}$ & Presentase (\%) \\
\hline Tinggi & 52 & 78,8 \\
Sedang & 14 & 21,2 \\
Rendah & & 0 & 0,0 \\
\hline & TOTAL & 66 & 100 \\
\hline
\end{tabular}

Pada Tabel 3hasil kategori tindakan responden dalam penggunaan plastik berada pada kategori tinggi sebanyak 52 orang dengan presentase $78,8 \%$. Tindakan diukur melalui pengisisan kuesioner tindakan responden dalam penggunaan plastik.

Uji keberartian regresi secara bersama-sama atau simultan dilakukan untuk mengetahui apakah model persamaan regresi berganda berarti atau tidak. Dari uji keberartian regresi diperoleh $F_{\text {hitung }}$ sebesar 44,395 dan $F_{\text {tabel }}$ sebesar 3,143. Ini menunjukkan $F_{\text {hitung }>} F_{\text {tabel }}$, maka disimpulkan bahwa model persamaan regresi berganda adalah signifikan atau berarti.

Pengujian signifikasi parsial dilakukan untuk mengetahui apakah terdapat hubungan signifikan antara variabel $\mathrm{Y}$ atas X1 dan $\mathrm{Y}$ atas X2. Berdasarkan hasil perhitungan yang dilakukan diperoleh $t_{\text {hitung }}$ sebesar 3,754 dan 8,877 dengan $t_{\text {tabel }}$ sebesar 1,997 . Hasil menunjukkan $t_{\text {hitung }} t_{\text {tabel }}$, maka terdapat hubungan yang signifikan antara variabel $\mathrm{X} 1$ dan X2 dengan variabel Y. 
Pengujian koefisien korelasi dilakukan dengan perhitungan produk moment, untuk mengetahui apakah terdapat hubungan positif atau tidak antara variabel X1 dan X2 dengan variabel Y. Hasil perhitungan menunjukkan $r_{\text {hitung }}(\mathrm{Rx} 1 \mathrm{x} 2 \mathrm{y})=0,765>r_{\text {tabel }}=0,244$, karena $r_{\text {hitung }}>0$ maka $H_{0}$ ditolak dan $H_{1}$ diterima. Dengan demikian, terdapat hubungan yang positif antara variabel X1 dan X2 dengan variabel Y.Untuk mengetahui seberapa besar kontribusi variabel X1 dan X2 terhadap variabel Y. Dari perhitungan uji koefisien determinasi, disimpulkan bahwa variabel $\mathrm{Y}$ ditentukan oleh variabel X1 dan X2 sebesar 58,5\%.

\section{Sub-Bagian dari Result}

1. Pengetahuan Responden

PadaTabel 1 menunjukkan bahwa kategori pengetahuan responden tentang plastik berada pada kategori tinggi hingga sedang, yaitu sebanyak 36 orang dengan presentase $54,5 \%$ berada dikategori tinggi dan 27 orang dengan presentase $40,9 \%$ berada dikategori sedang.Dari hasil tersebut berarti responden memahami pengetahuan umum tentang plastik, yaitu manfaat dan kegunaan plastik, nomor kode plastik, bahaya plastik, alternatif penggunaan plastik, dan lain-lain. Manusia memliki panca indera dan sebagian besar pengetahuan manusia diperoleh dari penglihatan dan pendengaran (mata dan telinga)(Surahman \& Supardi, 2016). Pengetahuan yang tinggi dapat didukung oleh beberapa faktor yang mempengaruhinya, yaitu usia, pendidikan responden, informasi yang didapat melalui pendidikan informal maupun nonformal, seperti koran, media sosial, televisi, dan lain-lain, serta pengalaman responden (Budiman \& Riyanto, 2013).

Sesuai dengan penelitian Setyowati dan Mulasari (2013)menunjukkan bahwa sebanyak 58,6\% pengetahuan ibu rumah tangga tentang pengelolaan sampah plastik tidak baik, hal ini dipengaruhi oleh informasi dan kegiatan penyuluhan kepada masyarakat di Dusun Kedesen lebih terfokus pada kesehatan.Sementara, penggunaan plastik tidak lepas dari kehidupan sehari-hari.Sampah yang tidak ditangani dengan baik akan menjadi bencana. Sampah plastik menjadi salah satu yang paling disorot, selain butuh ratusan tahun agar bisa terurai alam, sampah plastik yang tidak terkelola dan berakhir dilingkungan, berpotensi mencemari dan membahayakan ekosistem ([Kemenkeu RI] Kementrian Keuangan Republik Indonesia, 2019).Hasil penelitian Guslaida, dkk.(2014) penggunaan kantong plastik di Pasar Tradisional Firdaus Kecamatan Medan Tembung tidak berhubungan dengan faktor yang mempengaruhi pengetahuan yaitu umur dan pendidikan pembeli maupun pedagang. Tetapi terdapat hubungan antara penggunaan kantong plastik dengan faktor pekerjaan. Resiko dengan pekerjaan sebagai pembeli akan lebih banyak menggunakan kantong plastik dibandingkan dengan yang berkerja sebagai pedagang.

Penelitian milik Jumadewi (2019) menunjukkan sebanyak 78 orang (53,06\%) tidak mengetahui pentingnya cantuman kode dan jenis plastik. Hal ini berarti pengetahuan responden masih kurangdalam penggunaan plastik yang benar sesuai dengan jenisnya.Penggunaan plastik yang tidak sesuai nomor kodenya dapat mengakibatkan berbagai gangguan kesehatan, sehingga dapat memicu kanker dan kerusakan jaringan pada tubuh manusia (karsinogenik). Menjaga plastik saat digunakan untuk kemasan makanan dan minuman agar tidak berubah dan menggunakan plastik sesuai dengan nomer kode daur ulangnya adalah cara yang aman untuk menghindari dari bahaya tersebut.Jenis plastik yang digunakan untuk kemasan pangan sangatlah beragam, sehingga perlu pengetahuan yang baik untuk dapat menentukan jenis kemasan plastik yang tepat.

\section{Sikap Responden}

Sikap reponden dalam penggunaan plastik merupakan prediksi bagi tindakan sehari-hari, walaupun masih ada faktor lainnya, seperti lingkungan dan keyakinan seseorang. Hal ini berarti bahwa sikap bisa saja menentukan tindakan seseorang, tetapi sikap belum tentu menjadi tindakan seseorang.Menurut Notoatmodjo (2010) dalam Mardhiah et al., (2016) sikap menyangkut faktor pendapat dan emosi seseorang yang bersangkutan dan respon tertutup seseorang terhadap stimulus atau objek tertentu. Sikap merupakan kecenderungan berbuat yang menggambarkan rasa senang, tidak senang atau bahkan biasa-biasa saja dari seseorang terhadap suatu hal tertentu.

Berdasarkan Tabel 2 dapat diketahui kategori sikap responden dengan tindakan penggunaan plastik berada pada kategori tinggi sebanyak 63 orang dengan presentase 95,5\%. Hasil penelitian sikap diukur melalui sikap responden dalam penggunaan plastik, aturan penggunaan plastik, bahaya penggunaan plastik, dan lain-lain. Sikap responden yang berada pada kategori tinggi ini dapat disebabkan oleh beberapa faktor, diantaranya yaitu pengalaman pribadi, pengaruh orang lain, pengaruh budaya, media massa, dan lain-lain.

Sesuai dengan penelitian Jumadewi (2019) sebanyak 64,63\% mahasiswa menunjukkan sikap positif tentang bahaya penggunaan plastik sebagai wadah makanan dan minuman. Sikap positif ini didukung karena mahasiswa berada dalam pendidikan kesehatan, sehingga mahasiswa berusaha mencegah bahaya yang dapat mengganggu kesehatan.Sikap yang ada pada seseorang memerlukan stimulus dan respon. Sikap pada seseorang berbeda-beda, bila suka maka akan tertarik, mencari tahu, dan bergabung. Sebaliknya jika tidak suka akan menghindar dan 
menjauhi.Faktor yang mempengaruhi sikap bukan hanya berasal dari faktor internal saja, tetapi faktor eksternal juga dapat mempengaruhi pembentukan sikap.Sikap dapat bersifat positif ada juga yang bersifat negatif.Sejalan dengan penelitian Damanik (2012)bahwa sebanyak 92\% konsumen di Pusat Pasar Tavip Binjai memiliki sikap yang baik (positif) dalam penggunaan plastik kresek hitam daur ulang. Sikap baik ini disebabkan rata-rata konsumen memiliki pendidikan yang baik dalam penggunaan wadah makanan siap santap, sehingga konsumen memiliki pengetahuan yang baik pula.Tetapi sikap baik ini belumtentu menghasilkan tindakan yang baik juga.

Menurut Azwar (2007) dalam Budiman dan Riyanto (2013) ada beberapa faktor yang dapat mempengaruhi sikap seseorang, yaitu pengalaman pribadi yang sudah dialami atau sedang dialami akan mempengaruhi pembentukan sikap terhadap stimulus sosial. Tidak adanya pengalaman sama sekali dengan suatu objek psikologi cenderung akan membentuk sikap negatif terhadap suatu objek tersebut. Pengaruh orang lain yang dianggap penting dan pengaruh budaya dapat memberikan pengaruh pada sikap terhadap berbagai masalah, seperti dimana seorang hidup dan dibesarkan dapat mempengaruhi sikap melalui budaya disekitarnya. Media massayang memberi pesan-pesan yang membawa sugesti yang dapat mempengaruhi pemikiran seseorang. Lembaga pendidikan dan lembaga agama yang akanmeletakkan dasar pengertian dan konsep moral dalam individu. Serta pengaruh faktor emosional yang berfungsi sebagai penyalur frustasi atau pengalihan bentuk mekanisme pertahanan ego. Sikap yang seperti itu dapat berarti sikap yang sementara dan akan cepat berlalu, tetapi juga dapat bertahan lama.

\section{Tindakan Responden}

Tindakan adalah perilaku yang bermakna, yaitu perilaku berarti nyata dan ditujukan pada orang lain(Supraja, 2015).Tindakan dapat berupa positif dan negatif. Apabila seseorang tertarik dan melakukan kebiasaan yang baik bagi diri maupun lingkungannya, tindakan tersebut berupa positif. Sebaliknya bila tindakan itu negatif maka seseorang cenderung berbuat buruk bagi diri maupun lingkungannya.

Dapat dilihat pada Tabel 3 hasil kategori tindakan responden dalam penggunaan plastik beradapada kategori tinggi sebanyak 52 orang dengan presentase $78,8 \%$. Tindakan tersebut diukur melalui tindakan responden dalam penggunaan plastik.Hasil tindakan ini sesuai dengan hasil tingkat pengetahuan dan sikap yang dimiliki responden.Tindakan ini terbentuk dari kesadaran yang nyata pada diri seseorang. Dapat disimpulkan bahwa ketika tindakan sudah menjadi kebiasaan, maka secara otomatis tindakan itu akan terus menerus dilakukan. Namun ketika tindakan sudah tidak efektif, maka akan muncul usaha untuk memperbaikinya.

Berdasarkan hasil penelitian Ilmiawati, dkk. (2017)sebanyak 41\% penduduk kecamatan Bungus Teluk Kabung tidak tahu mengenai senyawa berbahaya yang dapat dilepas ketika membakar sampah. Adanya kebiasaan membakar sampah plastik di lingkungan rumah menunjukkan kebiasaan yang sulit dihilangkan.Menurut Hinkel dalam Wagiyo(2012) ada beberapa dasar teori tindakan yaitu, tindakan manusia didorong oleh kesadaran diri sendiri dan pengaruh dari luar dirinya, tindakan manusia memiliki tujuan, tindakan manusia tiga sudut pandang, yaitu menyangkut masa lalu, sekarang, dan masa yang akan datang, dan lain-lain. Kebiasaan yang buruk ini jika tidak diubah maka akan membahayakan lingkungan maupun kesehatan. Pembakaran sampah plastik akan mengeluarkan asap toksik yang apabila dihirup akan menyebabkan sperma menjadi tidak subur dan bisa menyebabkan terjadinya gangguan kesuburan (Karuniastuti, 2013).

Hasil penelitian Webb et al., (2013) dalam jurnal Polymers dengan judul "Plastic Degradation and Its Environmental Implications with Special Reference to Poly(ethylene terephthalate)", menyatakan bahwa jenis plastik PET sangat berbahaya bagi lingkungan. Plastik PET yang sudah terurai akan mencemari perairan di laut dan di darat. Partikel ini dapat termakan oleh hewan sehingga pada akhirnya akan meracuni manusia.Upaya yang dapat dilakukan untuk terhindar dari bahaya penggunaan plastik yaitu menggunakan bahan-bahan yang mudah terurai dan aman terhadap kesehatan maupun lingkungan seperti plastik yang berasal dari bahan organik.Seperti halnya Negara Jepang yang telah menemukan jenis plastik yang dapat terurai yang terbuat dari bahan organic, yaitu tumbuhan jagung.

\section{Hubungan Pengetahuan dan Sikap Mahasiswa dengan Tindakan Penggunaan Plastik}

Hasil perhitungan koefisien korelasi antara pengetahuan dan sikap dengan tindakan penggunaan plastik

mempunyai hubungan yang positif dan kuat sebesar $r_{\text {hitung }}(\mathrm{Rx} 1 \mathrm{x} 2 \mathrm{y})=0,765$. Dari uji koefisien determinasi diperoleh hasil 0,585 dengan presentase sebesar 58,5\%. Ini berarti kontribusi pengetahuan dan sikap mahasiswa dengan tindakan penggunaan plastik sebesar 58,5\%, sedangkan sebesar 41,5\% ditentukan oleh faktor lain. Faktor lain tersebut berkaitan dengan karakteristik individu seperti persepsi, tingkat pendidikan, kebiasaan individu, faktor ekonomi seperti harga, dan lain-lain (Surahman \& Supardi, 2016: 39).

Berdasarkan hasil perhitungan statistik yang dilakukan dapat diketahui bahwa terdapat hubungan yang positif dan signifikan antara Pengetahuan dan Sikap Mahasiswa Program Studi Tata Boga Universitas Negeri Jakarta dengan Tindakan Penggunaan Plastik Untuk Minuman Panas. Ini berarti apabila nilai variabel X1 (pengetahuan) 
dan X2 (sikap) bertambah, maka nilai variabel Y (tindakan) juga bertambah. Semakin banyak pengetahuan tentang plastik yang dimiliki oleh seseorang maka semakin baik pula sikap dan tindakan mereka dalam penggunaan plastik.

Penelitian ini sejalan dengan Nasution \& Harahap (2018) hasil uji statistik diperoleh nilai $\mathrm{p}=0,034$ dan $\mathrm{r}=$ 0,378, maka dapat disimpulkan bahwa terdapat hubungan yang bermakna antara pengetahuan dengan penggunaan kantong plastik dan memiliki korelasi cukup dengan arah positif. Dan sejalan dengan penelitian Setyowati dan Mulasari (2013) di Kecamatan Daha bahwa terdapat hubungan yang bermakna antara pengetahuan ibu rumah tangga terhadap perilaku masyarakat dalam mengelola sampah plastik, yaitu dengan nilai $\mathrm{p}=0,000$ ( $\mathrm{p}$ $<0,05)$. Pengetahuan yang dimiliki seseorang sangat berpengaruh pada informasi yang didapatkannya.Faktor internal dan eksternal menjadi faktor utama untuk mengetahui dan memahami mengapa seseorang melakukan perilaku tertentu. Bila informasi yang diterima adalah informasi yang salah maka akan menyebabkan kekeliruan dalam bersikap maupun bertindak.

\section{CONCLUSIONS}

Mahasiswa Pendidikan Tata Boga Universitas Negeri Jakarta memahami penggunaan plastik yang dibuktikan dari hasil ketiga aspek (pengetahuan, sikap dan tindakan) berada pada kategori tinggi dan memiliki hubungan yang positif dan signifikan dengan penggunaan plastik.Ini berarti semakin tinggi pengetahuan yang dimiliki mahasiswa tentang plastik maka akan semakin baik pula sikap serta tindakan mereka dalam penggunaan plastik khususnya untuk minuman panas, begitu juga sebaliknya semakin rendah pengetahuan yang dimiliki mahasiswa tentang plastik maka akan semakin buruk pula sikap serta tindakan mereka dalam penggunaan plastik khususnya untuk minuman panas.

\section{REFERENCES}

[Kemenkeu RI] Kementrian Keuangan Republik Indonesia. (2019). Media Keuangan Transparansi Informasi Kebijakan Fiskal: Bumi Dalam Kantong Plastik. Jakarta: Sekretariat Jenderal Kementerian Keuangan.

Budiman, \& Riyanto, A. (2013). Kapita Selekta Kuesioner Pengetahuan dan Sikap Dalam Penelitian Kesehatan. Jakarta: Salemba Medika.

Damanik, E. (2012). Perilaku Konsumen Dalam Penggunaan Plastik Kresek Hitam Daur Ulang Sebagai Wadah Makanan Siap Santap Di Pusat Pasar Tavip Binjai. Precure, 1, 8-14.

Guslaida, M., Naria, E., \& Santi, D. N. (2014). Hubungan Karakteristik Pengetahuan Sikap pada Pembeli dan Pedagang dengan Penggunaan Kantong Plastik di Pasar Tradisional Firdaus Kecamatan Medan Tembung Tahun 2014. Lingkungan Dan Keselamatan Kerja, 3, 1-8.

Ilmiawati, C., Reza, M., Rahmatini, \& Rustam, E. (2017). Edukasi Pemakaian Plastik sebagai Kemasan Makanan dan Minuman Serta Risikonya terhadap Kesehatan pada Komunitas di Kecamatan Bungus Teluk Kabung, Padang. Jurnal Ilmiah Pengabdian Kepada Masyarakat, 1, 20-28.

Jumadewi, A. (2019). Gambaran Perilaku Mahasiswa Tentang Bahaya Penggunaan Plastik Sebagai Wadah Makanan Dan Minuman Prodi D3 Keperawatan Tapaktuan. Majalah Kesehatan Masyarakat Aceh (MaKMA), 2, 69-79.

Karuniastuti, N. (2013). Bahaya Plastik Terhadap Kesehatan dan Lingkungan. Forum Teknologi, 3, 6-14.

Mardhiah, A., Abdullah, A., \& Hermansyah. (2016). Pendidikan Kesehatan Dalam Peningkatan Pengetahuan, Sikap Dan Keterampilan Keluarga Dengan Hipertensi - Pilot Study. Jurnal Ilmu Keperawatan, 3.

Nasution, N. H., \& Harahap, Y. W. (2018). Hubungan Pengetahuan Karyawan Stikes Aufa Royhan Dengan Penggunaan Kantong Plastik. Indonesian Health Scientific Journal, 3, 22-28.

Purwaningrum, P. (2016). Upaya Mengurangi Timbulan Sampah Plastik Di Lingkungan. Indonesian Journal of Urban and Environmental Technology, 8, 141. 
Qodriyatun, S. N. (2018). Sampah Plastik: Dampaknya Terhadap Pariwisata dan Solusi. Pusat Penelitian Badan Keablian DPR RI, 10, 13-18.

Setyowati, R., \& Mulasari, S. A. (2013). Pengetahuan dan Perilaku Ibu Rumah Tangga dalam Pengelolaan Sampah Plastik. Kesmas: National Public Health Journal, 7, 562-566.

Sucipta, I. N., Suriasih, K., \& Kenacana, P. K. . (2017). Pengemasan Pangan: Kajian Pengemasan Yang Aman, Efisien, Efektif Dan Efesien. Bali: Udayana University Press.

Supraja, M. (2015). Alfred Schutz : Rekonstruksi Teori Tindakan Max Weber. Jurnal Pemikiran Sosiologi, 1, 81.

Surahman, \& Supardi, S. (2016). Ilmu Kesehatan Masyarakat PKM. Jakarta: Kementrian Kesehatan RI.

Surono, U. B. (2013). Berbagai Metode Konversi Sampah Plastik. Jurnal Teknik, 3, 32-40.

Wagiyo. (2012). Paradigma Sosiologi dan Teori Pendekatannya. Tangerang: Universitas Terbuka.

Webb, H. K., Arnott, J., Crawford, R. J., \& Ivanova, E. P. (2013). Plastic Degradation and Its Environmental Implications with Special Reference to Poly(ethylene terephthalate). Polymers, 5, 1-18.

World Bank Group. (2018). Hotspot Sampah Laut Indonesia. Jakarta: Kerjasama World Bank Group, Kementerian Koordinator Bidang Kemaritiman. 